\title{
Evidence for Two Ferryl Species in Chloroperoxidase Compound II
}

Kari L. Stone, ${ }^{a}$ Lee M. Hoffart, ${ }^{\mathrm{b}}$ Rachel K. Behan, ${ }^{\mathrm{a}}$ Carsten Krebs, ${ }^{\mathrm{a}, \mathrm{b}}$ and Michael T. Green $^{\text {a* }}$

Department of Chemistry, ${ }^{a}$ and Biochemistry and Molecular Biology ${ }^{b}$, The Pennsylvania State University, University Park, Pennsylvania 16802

\section{Reference:}

\section{Supporting Information}

32. Frisch, M. J.; Trucks, G. W.; Schlegel, H. B.; Scuseria, G. E.; Robb, M. A.; Cheeseman, J. R.; Montgomery, J. J. A.; Vreven, T.; Kudin, K. N.; Burant, J. C.; Millam, J. M.; Iyengar, S. S.; Tomasi, J.; Barone, V.; Mennucci, B.; Cossi, M.; Scalmani, G.; Rega, N.; Petersson, G. A.; Nakatsuji, H.; Hada, M.; Ehara, M.; Toyota, K.; Fukuda, R.; Hasegawa, J.; Ishida, M.; Nakajima, T.; Honda, Y.; Kitao, O.; Nakai, H.; Klene, M.; Li, X.; Knox, J. E.; Hratchian, H. P.; Cross, J. B.; Bakken, V.; Adamo, C.; Jaramillo, J.; Gomperts, R.; Stratmann, R. E.; Yazyev, O.; Austin, A. J.; Cammi, R.; Pomelli, C.; Ochterski, J. W.; Ayala, P. Y.; Morokuma, K.; Voth, G. A.; Salvador, P.; Dannenberg, J. J.; Zakrzewski, V. G.; Dapprich, S.; Daniels, A. D.; Strain, M. C.; Farkas, O.; Malick, D. K.; Rabuck, A. D.; Raghavachari, K.; Foresman, J. B.; Ortiz, J. V.; Cui, Q.; Baboul, A. G.; Clifford, S.; Cioslowski, J.; Stefanov, B. B.; Liu, G.; Liashenko, A.; Piskorz, P.; Komaromi, I.; Martin, R. L.; Fox, D. J.; Keith, T.; Al-Laham, M. A.; Peng, C. Y.; Nanayakkara, A.; Challacombe, M.; Gill, P. M. W.; Johnson, B.; Chen, W.; Wong, M. W.; Gonzalez, C.; Pople, J. A. Gaussian 03; Gaussian, Inc.: Wallingford CT, 2004.

Legends for Supporting Figures and Table:

Figure S1: Mössbauer spectrum of CPO-II, pH 4.5, recorded at 4.2K in a 40mT magnetic field applied parallel to the $\gamma$ beam. CPO-II was prepared in a rapid mixing experiment where ${ }^{57} \mathrm{Fe}$-enriched $\mathrm{CPO} /$ ascorbate in $0.1 \mathrm{M}$ acetate, $\mathrm{pH} 4.5$, ( $4 \mathrm{mM}$ and $37.5 \mathrm{mM}$, respectively) was mixed with peracetic acid in $0.1 \mathrm{M}$ acetate, $\mathrm{pH} 4.5,(75 \mathrm{mM})$ in a 2:1 ratio and quenched in a cold isopentane bath $\left(-145^{\circ} \mathrm{C}\right)$ after $28 \mathrm{~ms}$. The spectrum shows raw data; solid line is best fit to two quadrupole doublets. The parameters for the protonated ferryl $\left(\Delta \mathrm{E}_{\mathrm{Q}}=2.08 \mathrm{~mm} / \mathrm{s}, \delta=0.10 \mathrm{~mm} / \mathrm{s}, \sim 66 \%\right)$ and the ferryl $\left(\Delta \mathrm{E}_{\mathrm{Q}}=1.58 \mathrm{~mm} / \mathrm{s}\right.$, $\delta=0.11 \mathrm{~mm} / \mathrm{s}, \sim 34 \%$ ) are similar to parameters measured for CPO-II at $\mathrm{pH}$ 6.5 .

Figure S2: Mössbauer spectrum of CPO-II, $\mathrm{pH}$ 6.5, prepared with p-phenolsulfonic acid as the reductant. CPO-II was prepared in a rapid mixing experiment where ${ }^{57} \mathrm{Fe}$-enriched $\mathrm{CPO} / p$-phenolsulfonic acid (4mM and $37.5 \mathrm{mM}$, respectively) in $0.1 \mathrm{M}$ KPhos, $\mathrm{pH} 6.5$, was mixed in a 2:1 ratio with peracetic acid $(75 \mathrm{mM})$. The reaction was quenched in a cold isopentane bath $\left(-145^{\circ} \mathrm{C}\right)$ after $5 \mathrm{~ms}$. Spectra were collected over a range of Doppler velocities of approximately \pm $4 \mathrm{~mm} / \mathrm{s}$ (left panel) or $\pm 8 \mathrm{~mm} / \mathrm{s}$ (right panel). Removal of $20 \%$ of ferric CPO from the raw data (A) yields the spectra shown in (B). Removal of $35 \%$ of CPO-I yields the spectra shown in (C). These spectra have been simulated with two quadrupole doublets with the following parameters: $\delta(1)=0.10$ $\mathrm{mm} / \mathrm{s}, \Delta \mathrm{E}_{\mathrm{Q}}(1)=2.07 \mathrm{~mm} / \mathrm{s}, 32 \%$ of total intensity, and $\delta(2)=0.10 \mathrm{~mm} / \mathrm{s}$, $\Delta \mathrm{E}_{\mathrm{Q}}(2)=1.58 \mathrm{~mm} / \mathrm{s}, 13 \%$ of total intensity. These parameters and the ratio of the relative intensities are similar to those observed for CPO-II with ascorbate as the reductant. 
Figure S3: Mössbauer spectrum of CPO-II prepared with hydrogen peroxide as the oxidant. CPO-II was prepared in a rapid mixing experiment where ${ }^{57} \mathrm{Fe}-$ enriched $\mathrm{CPO} /$ ascorbate ( $4 \mathrm{mM}$ and $37.5 \mathrm{mM}$, respectively) in $0.1 \mathrm{M}$ KPhos, $\mathrm{pH} 6.5$ was reacted in a 2:1 ratio with hydrogen peroxide $(75 \mathrm{mM})$ and quenched in a cold isopentane bath $\left(-140^{\circ} \mathrm{C}\right)$ after $28 \mathrm{~ms}$. The spectrum shows raw data; solid line is best fit to two quadrupole doublets. A) The sample contained 65\% ferric CPO and was removed from the raw data. B) The remaining iron showed two doublets: $69 \%\left(\Delta \mathrm{E}_{\mathrm{Q}}=2.08 \mathrm{~mm} / \mathrm{s}, \delta=0.10 \mathrm{~mm} / \mathrm{s}\right)$ assigned as the protonated ferryl and 31\% $\left(\Delta \mathrm{E}_{\mathrm{Q}}=1.58 \mathrm{~mm} / \mathrm{s}, \delta=0.11 \mathrm{~mm} / \mathrm{s}\right)$ assigned as the ferryl. These parameters are similar to parameters measured for CPO-II with peracetic acid as the oxidant.

Table S1: Mössbauer parameters under various conditions for CPO-II formation. 


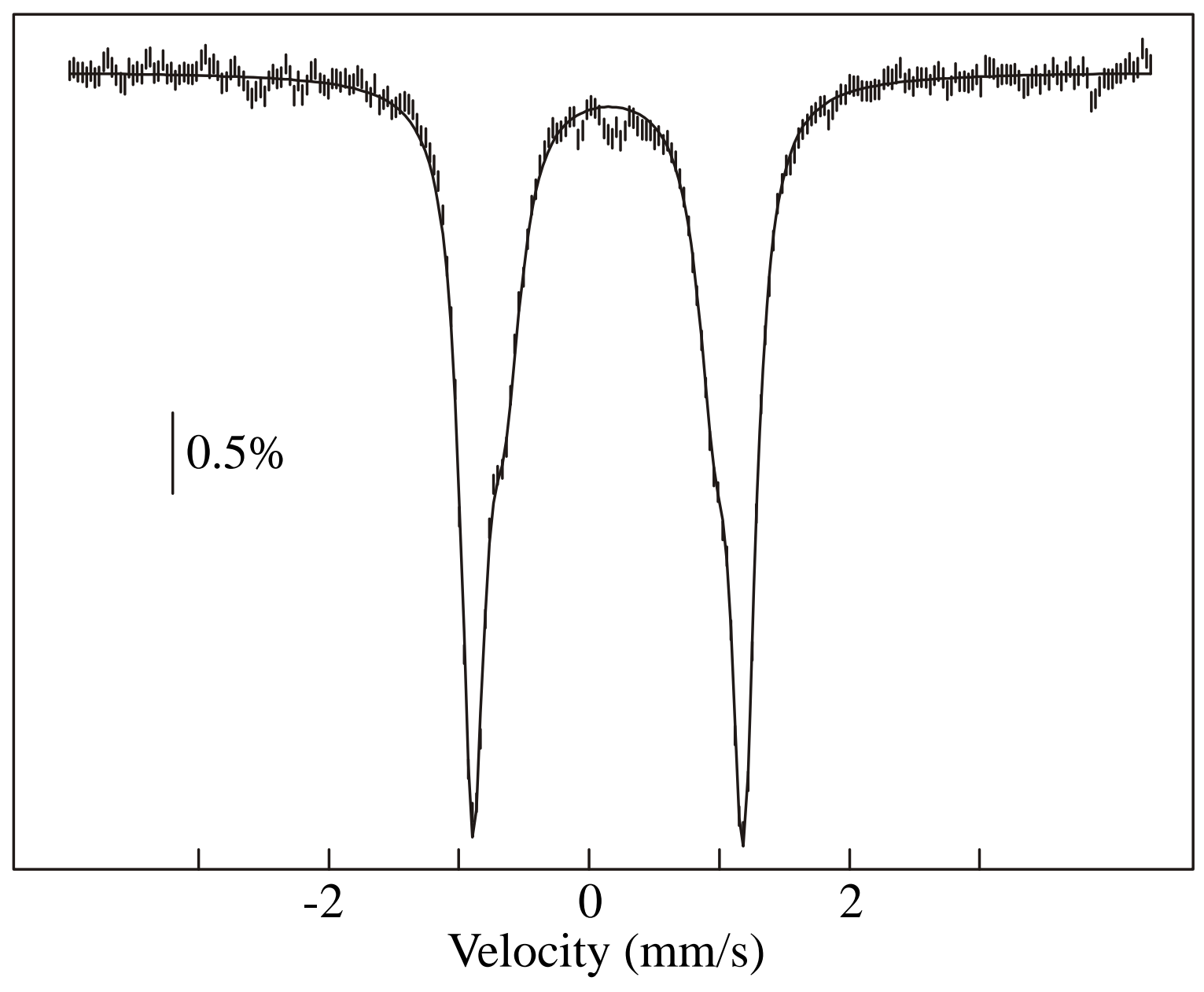

Stone, et al. Figure S1 


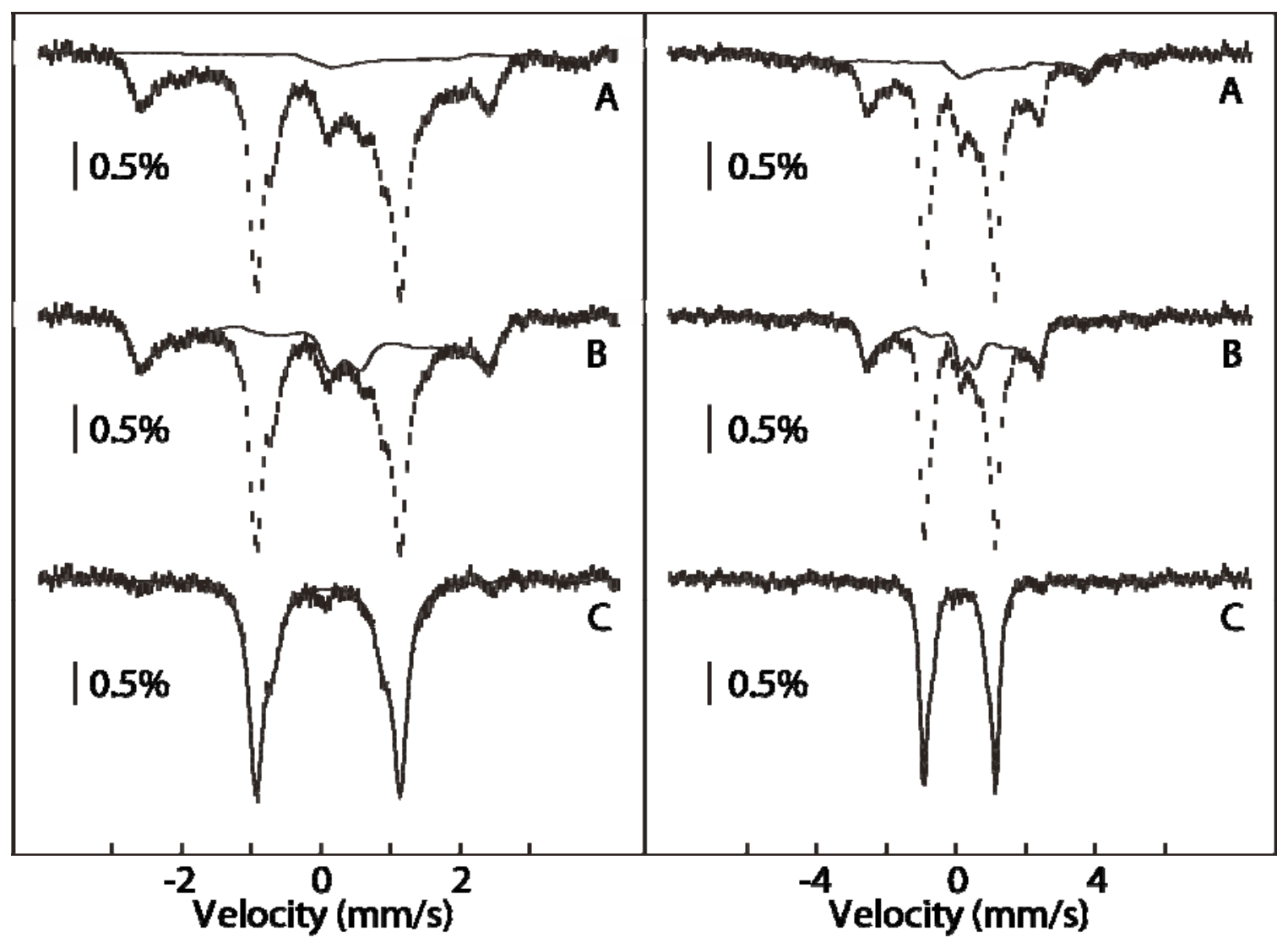

Stone, et al. Figure S2 


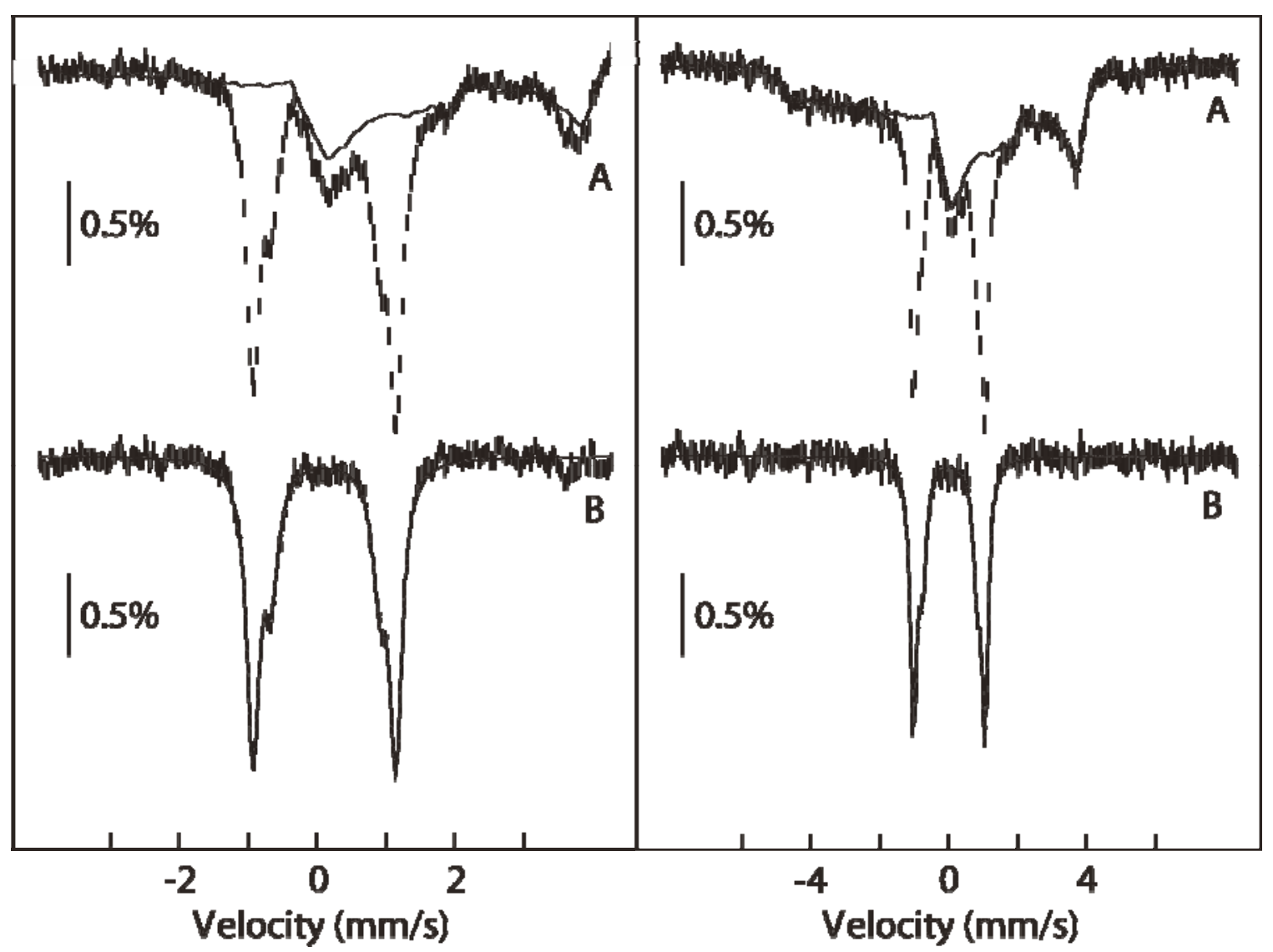

Stone, et al. Figure S3 
Table S1: Mössbauer parameters for CPO-II

\begin{tabular}{ccccc} 
& \multicolumn{2}{c}{ Protonated Ferryl } & \multicolumn{2}{c}{ Ferryl } \\
\cline { 2 - 5 } & $\delta(\mathbf{m m} / \mathbf{s})$ & $\Delta \mathbf{E}_{\mathbf{Q}}(\mathbf{m m} / \mathbf{s})$ & $\delta(\mathbf{m m} / \mathbf{s})$ & $\Delta \mathbf{E}_{\mathbf{Q}}(\mathbf{m m} / \mathbf{s})$ \\
\hline PA/Ascorbate pH 4.5 & 0.10 & 2.08 & 0.10 & 1.61 \\
PA/Ascorbate pH 6.5 & 0.10 & 2.06 & 0.11 & 1.59 \\
Annealed CR-CPO-I & 0.10 & 2.08 & 0.11 & 1.6 \\
p-PSA/PA pH 6.5 & 0.10 & 2.07 & 0.10 & 1.58 \\
$\mathrm{H}_{2} \mathrm{O}_{2}$ /Ascorbate pH 6.5 & 0.10 & 2.08 & 0.11 & 1.58 \\
\hline
\end{tabular}

Abbreviations: CPO-II: Chloroperoxidase compound II; PA: peracetic acid; CR-CPO-I: cryoreduced Chloroperoxidase compound I; $p$-PSA: $p$-phenolsulfonic acid

Stone, et al. Table S1 